\title{
UPAYA WANITA MENOPAUSE DALAM MENJAGA KEUTUHAN RUMAH TANGGANYA
}

\author{
Kamsiah \\ Universitas Islam Negeri Sultan Aji Muhammad Idris Samarinda \\ Email: sie4r4@gmail.com

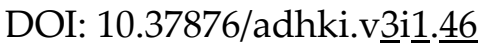

\begin{abstract}
When a woman has undergone menopause or cessation of menstruation, as estrogen hormone levels begin to decrease, this will greatly affect physiology especially on the intimate organs and repoduksi and result in decreased biological arousal. The purpose of this study is to find out how menopausal women live their sexual lives and know how to maintain harmony in their households and to know how Islamic law views menopausal women's households. This research is descriptive analytical research, which is research that describes the efforts of menopausal women to maintain harmony in their household by using qualitative data collection methods. The primary data source is sourced from information and interview results of menopausal women numbering 10 respondents in Loa Bakung Village, as for the secondary data taken from the Qur'an Karim, fiqh books and writings related to research, then the data is analyzed using the concept of Islamic law. The result of this study is that when menopausal women begin to enter the climacterium period and greatly affect their biological arousal so that the women try to find solutions such as by doing regular self-care doing sports such as gymnastics, some ask for understanding in her husband even some who allow their husbands to be polygamous. This is done so that the relationship between her husband and her household remains harmonious and remains a family of sakinah mawaddah and rahmah with peace, love and affection, even though it has entered old age.
\end{abstract}

Keywords: Menopause, Harmony, Household

\begin{abstract}
Abstrak
Ketika seorang wanita telah mengalami menopause atau berhentinya menstruasi, karena kadar hormone estrogen mulai berkurang, hal ini akan sangat berpengaruh pada fisiologi terutama pada bagian organ intim dan repoduksi dan mengakibatkan gairah biologis menurun. Tujuan penelitian ini adalah mengetahui bagaimana wanita menopause menjalani kehidupan seksualnya dan mengetahui bagaimana upaya untuk menjaga keharmonisan rumah tangganya serta mengetahui bagaimana pandangan hukum Islam terhadap rumah tangga wanita menopause. Penelitian ini adalah penelitian deskriptif analitis, yaitu penelitian yang menggambarkan upaya wanita menopause menjaga keharmonisan rumah tangganya dengan menggunakan metode pengumpulan data kualitatif. Sumber data primer bersumber dari informasi dan hasil wawancara terhadap wanita menopause berjumlah 10 responden di Kelurahan Loa Bakung, adapun data skunder yang diambil dari Al-Qur'an Karim, kitab fikih dan tulisan-tulisan yang terkait denan penelitian, kemudian data dianalisis menggunakan konsep hukum Islam. Hasil penelitian ini adalah ketika wanita menopause mulai memasuki masa klimakterium dan sangat mempengaruhi gairah biologisnya sehingga para wanita tersebut berupaya mencari solusi di antaranya adalah dengan melakukan perawatan diri rutin melakukan olahraga seperti senam, adapula yang meminta pengertian pada suaminya bahkan ada yang merelakan suaminya untuk berpoligami. Ini dilakukan agar hubungan terhadap suami dan rumah tangganya tetap harmonis dan tetap menjadi keluarga sakinah mawaddah dan rahmah dengan ketenangan kedamaian, cinta dan kasih sayang, meskipun telah memasuki usia tua.
\end{abstract}

Kata Kunci: Menopause, Keharmonisan, Rumah Tangga

Volume 3, Nomor 1, Juni 2021 (35-50) 


\section{Pendahuluan}

Di dalam Al-Qur'an yang dirangkum dalam Fikih Pernikahan yaitu di antara hal yang dapat menjadikan hubungan dalam rumah tangga menajadi sakinah, mawaddah dan rahmah yang maknanya adalah adanya kedamaian, ketenangan dan rasa kasih sayang atau disebut juga harmonis adalah ketika keduanya bisa saling bertanggung jawab serta melaksanakan hak dan kewajiban masing-masing sebagai pasangan suami isteri. ${ }^{3}$ Salah satunya adalah hak untuk digauli. Sebagaimana diterangkan di dalam AlQur'an surah An-Nisa ayat 19, yaitu:4.

Hubungan intim antara suami isteri itu sendiri merupakan fitrah yang diberikan oleh Allah, SWT kepada pasangan suami ataupun isteri, yang juga sering disebut dengan pemberian nafkah batin. Sebagaimana firman Allah, SWT di dalam Al-Qur'an surah Al-Baqarah ayat $223 .^{5}$

Ayat tersebut pada dasarnya ditujukan pada para suami yang memegang peran penting di dalam kehidupan rumah tangga yaitu orang yang dibebankan kepadanya tanggung jawab sebagai pemberi nafkah dan secara fitrahnya biasanya lebih dominan mengutamakan kenyamanan hubungan intim terhadap isterinya. Ibnu Hazm berpendapat bahwa wajibnya seorang suami untuk menggauli isterinya minimal satu kali dalam masa sucinya, jika mampu untuk melakukannya, jika tidak maka beliau berpendapat bahwa suami itu telah bermaksiat kepada Allah, SWT. Hal ini berdasarkan firman- NYA di dalam Al-Qur'an Surah Al-Baqarah ayat 222. ${ }^{6}$

Jumhur ulama sepakat dengan pendapat Ibnu Hazm tersebut, bahwa seorang suami wajib menggauli isterinya jika tidak ada halangan. ${ }^{7}$ Dan ini merupakan hak bagi isteri yang harus didapatkan dari suaminya. Jika berbicara tentang hak isteri atas suaminya, tentu tidak kalah pentingnya isteri juga mempunyai kewajiban untuk mentaati dan melayanai serta memberikan hak suaminya, baik hak lahir terlebih hak batinnya.

Islam sendiri sangat mengapresiasi terhadap wanita yang selalu memberikan hak suami dan senantiasa mentaati suaminya sebagaimana Hadits Nabi, SAW, yang artinya: Dari Abu Hurairah, R.A, dia berkata "Pernah ditanyakan kepada Rasulullah, SAW "siapakah wanita yang paling baik?" Beliau menjawab "yaitu yang paling menyenangkan jika dilihat suaminya, mentaati suami jika diperintah, dan tidak menyelisihi suami pada diri dan hartanya, sehingga membuat suami benci". (HR. An-Nasa'i no.3231). ${ }^{8}$

Oleh karenanya menjalankan hak dan kewajiban ini adalah hal yang sangat penting dalam kehidupan rumah tangga. Serta ketaatan seorang isteri merupakan modal agar terjalinnya kelanggengan rumah tangga tersebut. Hal ini akan dapat terjaga jika ada keseimbangan kemauan, kekuatan dan kenyamanan serta saling cinta suami

${ }^{3}$ Beni Ahmad Saebeni, Fikih Munakahat, (Bandung: Pustaka Setia, 2001), h. 14.

${ }^{4}$ Nur Ahmad, "Konseling Pernikahan Berbasis Asmara" (As-Sakinah, Mawaddah, Warahmah), dalam Jurnal Konseling Religi, (Stain Kudus: Jawa Tengah Vol. 7, No. 2 Tahun 2016).

${ }_{5}^{5}$ Siti Chodijah, Karakteristik Keluarga Sakinah Dalam Islam, (Jurnal Rausyan Fikr, Volume 14, No 1.

${ }^{6}$ Beni Ahmad Saebeni, Fikih,..., h. 16.

7 Syaikh Sulaiman Ahmad Yahya Al-Faifi, Ringkasan, Fikih Sunnah Sayyid Sabiq, (Jakarta: Pustaka Al-Kautsar, 2013), h. 476.

${ }^{8}$ Hadis Riwayat An-Nasa'i, No. 3231, dalam kitab An-Nikaah no. 7373. Hadis ini dihasankan oleh Syaikh Al-Bani dalam kitab Ash-Shahihah no. 1838.

ADHKI: Journal oāf Islamic Family Law 
isteri tersebut, khususnya dalam hal mendapatkan hak kenyamanan dalam hubungan intim. Oleh karenanya Islam sendiri mengangap hubungan intim suami isteri merupakan perbuatan ibadah. Jika hal itu tidak terpenuhi maka bisa jadi akan menjadi penyebab hilangnya kebahagiaan dan keharmonisan suami isteri tersebut serta berubahnya situasi yang disebut sakinah, mawaddah dan rahmah dalam keluarga itu. Di antara sebab hilangnya keharmonisan tersebut adalah menurunnya kwalitas dan kwantitas hubungan seksual antara suami dan isteri yang merupakan salah satu kebutuhan yang sangat penting bagi keduanya. ${ }^{9}$

Pemicu menurunnya kwalitas dan kwantitas seksualitas ini bisa disebabkan dari berbagai faktor, baik itu faktor internal ataupun eksternal, di antara faktor internal yang terjadi, yaitu isteri yang telah berhenti haid disebabkan karena menopause, suatu hal yang tidak dapat dihindari oleh seorang wanita, di mana berubahnya organ reproduksi yang pada umumnya terjadi pada usia lima puluh tahun, disebabkan berkurangnya sedikit demi sedikit hormone estrogen (pembentukan hormone wanita), di mana Ovarium (indung telur) berhenti menghasilkan sel telur dan pada akhirnya berhentinya menstruasi. ${ }^{10}$

Masalah menopause ini memang sangat berpengaruh terhadap aktivitas biologis seorang isteri terhadap suami, yang kemudian bisa mengganggu stabilitas hubungan antara keduanya. Adanya perubahan gairah biologis di masa klimakterium (Hal ini dapat menyebabkan menurunnya gairah seksual). Menurunnya gairah biologis disebabkan karena berkurangnya lubrikasi hingga membuat vagina menjadi kering, kenikmatan bercinta menurun tajam hingga kesulitan orgasme. ${ }^{11}$ Bahkan anggapan para wanita ini semestinya tidak lagi melakukan aktifitas biologis karena dianggap bisa menimbulkan penyakit. Meskipun sebetulnya tidak ada bukti berdasarkan observasi peneliti tentang penyakit apa yang akan dialami para wanita tersebut.

Masalah menopause ini menjadi ketegangan terhadap beberapa pasangan suami isteri yang sudah lama menjalin rumah tangga di Kelurahan Loa Bakung, Kecamatan sungai Kunjang, Kota Samarinda, usia para isteri pada umumnya telah mencapai 50 tahun, kemudian hal ini pula yang menjadi ketertarikan penulis untuk meneliti bagaimana kehidupan rumah tangga pasangan yang isterinya telah mengalami menopause di Kelurahan Loa Bakung tersebut. Masalah menopause inilah yang menimbulkan beberapa hal yang sangat erat sekali dengan keharmonisan pasangan tersebut. Di antara problem yang dihadapi pasangan-pasangan tersebut yaitu enggannya isteri untuk melayani suaminya dengan alasan sakit dan hilangnya gairah untuk melakukan hubungan biologis itu sendiri dan ini tentu akan menjadi masalah untuk para suami meskipun hubungan biologis sesungguhnya bukanlah segalanya. Namun pada umumnya seorang laki-laki tidak pernah kehilangan gairah untuk melakukan hubungan biologis selama laki-laki itu sehat walaupun ketika laki-laki itu

\footnotetext{
${ }_{9}^{9}$ Thariq Kamal an-Nu'aimi, Psikologi Suami Istri, (Yogyakarta: Mitra Pustaka 2005), h. 585.

${ }^{10}$ Lestary, D. Seluk Beluk Menopause, (Jogjakarta: Garailmu, 2010), h. 20.

${ }_{11}$ Yati Afiyanti \& Anggi Pratiwi, Seksualitas dan Kesehatan Reproduksi Perempuan, (Jakarta: Rajawali Pers, 2016), h. 33.
} 
mengalami perubahan fisik karena usia ${ }^{12}$. Selain itu hal lain yang menjadi momok menakutkan bagi para isteri terhadap menopause ini yaitu adalah selain hilangnya semangat dan gairah biologisnya, kemudian ditambah lagi pengaruh psikologis yang dialami wanita tersebut dengan berbagai perasaan di antarnya perasaan mudah tersinggung dan lain sebagainya ditambah perasaan takut akan suaminya berpaling kepada wanita lain akibat tidak dapat maksimalnya melayani suaminya dalam hubungan biologis.

Di dalam Islam melayani suami adalah sebuah kewajiban bagi seorang isteri, terlepas dari apakah isteri tersebut telah menopause, karena Islam sendiri tidak membatasi usia untuk melayani suaminya melakukan hubungan intim, selama suaminya berkeinginan untuk hal itu maka isteri wajib melayaninya. Dan jika isteri mulai enggan untuk melayani suaminya maka bisa saja dikatakan isteri tersebut melakukan nusyuz, Imam Syafi'i mengatakan nusyuz juga termasuk enggannya seorang isteri melayani suaminya dalam melakukan hubungan biologis. ${ }^{13} \mathrm{Hal}$ inilah yang bisa berimbas pada perubahan prilaku suaminya terhadap isteri tersebut.

Dari hasil observasi yang dilakukan peneliti, ada dua orang suami yang melakukan poligami sirri karena alasan isterinya telah menopause. Meski wanita tersebut harus merelakan suaminya menikah lagi dengan wanita lain namun isteri tersebut tetap berusaha mempertahankan rumah tangganya. Meski pada dasarnya kebanyakan wanita tidak mau dipoligami, sekalipun masalah itu dianggap datang dari isteri tersebut seperti tidak lagi maksimal melayani kebutuhan biologis suaminya. ${ }^{14}$ Sebagaimana beberapa kasus yang terjadi di Kelurahan Loa bakung yang merupakan objek penelitian. Oleh sebab itu masalah menopouse ini bukan hal yang sepele karena sangat besar sekali pengaruhnya, bagi kehidupan rumah tangga pasangan suami isteri di Kelurahan tersebut dan perlunya solusi dan serta pengetahuan tentang bagaimana mengatasi keadaan rumahtangga wanita yang sudah mengalami menopause.

Menopause ini, selain menjadi penyebab beberapa wanita menjadi tidak percaya diri terhadap pasangannya, sehingga enggan melayani suaminya melakukan hubungan intim lagi, karena berbagai alasan sebagaimana telah disebutkan juga harus merelakan dirinya dipoligami. Namun adapula dari beberapa wanita yang menjadi respoden peneliti yang justru merasa senang saat masa menopause itu datang dengan alasan tidak lagi direpotkan dengan menstruasi, dan melakukan kegiatan ibadah seperti sholat, puasa dan lain sebagainya sudah tidak lagi terkendala dengan menstruasinya, meskipun demikian, wanita tersebut ingin tetap tampil prima dan maksimal di hadapan suaminya, agar suaminya jangan sampai berpaling kepada wanita lain, dengan melakukan berbagai upaya sebagai solusi untuk terus menjaga keutuhan dan keharmonisan rumah tangganya. Ini terlihat dari pasangan suami istri ibu RC yang isterinya telah menopause. Namun wanita tersebut tetap berusaha dengan berbagai upaya seperti melakukan perawatan khusus kesehatan organ kewanitaan dan

${ }^{12}$ Aubrey M. Hill, Viropause- Andropause atau Menopause Laki- laki, (Jogjakarta: Pustaka Pelajar 2010), h. 11 .

${ }^{13}$ Mokh. Fadhlun, Nusyuz Menurut Pendapat Imam Abu Hanifah dan Imam Syafi'i, (UIN Sunan Kali Jaga, Jogjakarta).

${ }^{14}$ Iffah Qanita Nailiya, Poligami, Berkah Ataukah Musibah, (Jogjakarta: Diva Press, 2016), h. 51. 
kecantikannya dengan rutin pergi ke dokter dan mengkonsumsi makanan dan buahbuahan sehat sesuai anjuran dari dokter, serta ada pula yang mengkonsumsi jamujamuan tradisional yang notabenenya merupakan resep dari nenek moyang wanita tersebut yang telah turun temurun.

Dari apa yang para wanita menopause itu lakukan dapat diartikan bahwa itu merupakan upaya agar rumah tangga mereka tetap utuh dan harmonis sehingga bernilai sakinah, mawaddah dan rahmah. Namun dari beberapa wanita yang diteliti ada pula yang tampil apa adanya, akan tetapi tetap berupaya meyakinkan dengan sungguhsungguh kepada suaminya bahwa dengan usia mereka haruslah bisa saling menjaga keutuhan rumah tangganya apalagi mereka sudah mempunyai anak yang sudah dewasa bahkan mempunyai cucu, dan merasa malu jika sampai hal biologis menjadi sebuah permasalahan suami isteri tersebut, meskipun mereka tidak lagi melakukan hubungan intim, disebabkan isteri tersebut merasa tidak sanggup dan tidak mempunyai kemampuan dan keinginan lagi untuk hal tersebut.

\section{Menopause dan Upaya Istri dalam Mempertahankan Rumah Tangga}

Menopause merupakan sebuah bahasa dari Yunani, yang maksudnya adalah "bulan" atau penghentian sementara. Secara istilah yaitu berhentinya menstruasi secara permanen dan berakhir pula masa reproduksi. Masa menopause ini ditandai dengan berhentinya menstruasi karena berubahnya hormone. Ahli kesehatan biasa mengunakan ini dengan istilah klimakterium yaitu terjadinya perubahan hormone karena menurunnya kadar estrogen dan progesterone yang dihasilkan indung telur, hal ini biasanya terjadi ketika wanita tersebut masih mengalami menstruasi beberapa tahun sebelum terjadinya menopause. ${ }^{1}$

1. Tahapan Menopause

Klimaksterium adalah sebuah bahasa dari Yunani yang bermakna "selangkah di atas tangga," pengertian tersebut juga diartikan masa peralihan terhadap akhir reproduksi yaitu dimulai pada usia 40 tahun dan berlanjut masa berhenti secara permanennya menstruasi pada umumnya usia 50 tahun, kemudian beralih ke masa senium atau lanjut usia pada umumnya usia 65. Tahapan ini dibagi dalam tiga bagian. ${ }^{2}$ Yaitu:

a. Pramenopause

Masa ini dialami sebelum terjadinya menopause yaitu 4 hingga 5 tahun sebelumnya. Hal ini ditandai dengan berkurangnnya respon terhadap hormone pituitari. ${ }^{3}$ Hormone pituitari sendiri adalah sebuah kelenjar dari dasar otak yang bereaksi terhadap senyawa kimia gonado trophin releasing hormone yang berasal dari hipotalamus yang akan mengeluarkan hormone yaitu FSH (Follicle Stimulating Hormone). Maka hormone inilah yang

\footnotetext{
${ }^{1}$ Emma, S. Wirakusumah, Tetap Sehat, Cantik, dan Bahagia Di Masa Menopuase Dengan Terapi Estrogen Alami, (Jakarta: Gramedia Pustaka Utama, 2003), h. 1.

${ }^{2}$ Heffner Linda. J \& Schrust. DJ, At a Glance Sistem Reproduksi, (Jakarta: PT Global Aksara Pratama, 2008), h. 30.

${ }^{3}$ Heffner. L.J, \& Schurt, D.J, At a Glance Sistem Reproduksi, (Jakarta: PT Gelora Aksara Pratama, 2008), h. 31
} 
menyebabkan terjadinya folikel di ovarium yang di dalamnya terdapat telur menjadi matang. Bereaksinya kelenjar hipotalamus dan pituitari terhadap estrogen dan dengan mengeluarkan sedikit follicle stimulating hormone ketika folikel telah matang dan kelenjar pituitari akan mengeluarkan hormone lain yaitu Luitenizing Hormone dan melepaskan folikel kemudian memicu ovum turun ke dalam tabung fallopi ke uterus dan hal ini disebut dengan ovulasi dan ini terjadinya 14 hari sebelum seorang wanita mengalami menstruasi. ${ }^{4}$ Ketika terjadinya menstruasi disertai dengan otot-otot uterus akan berkontraksi karena pengaruh senyawa kimia yaitu prostaglandin, yang menjadi penyebab timbulnya rasa sakit, pegal, nyeri yang dialami wanita ketika menstruasi. Hal ini bisa disebabkan juga ketidak seimbangan hormone-hormone yang dikenal dengan sebutan PMS atau Premenstruasi Syndrom yang belum diketahui seperti apa mekanismenya. ${ }^{5}$ Pada masa pramenopause ini juga selain kadar estrogen yang mulai berkurang ditambah menurunnya fungsi ovarium yang lambat laun akan berhenti. Juga berpengaruh pada kadar menstruasi dari banyak hingga menjadi sedikit dan berangsur-angsur menjadi hilang sama sekali. ${ }^{6}$

b. Post Menopause

Berhentinya menstruasi seorang wanita secara permanen. Ini akan dilihat selama lebih kurang satu tahun setelah tidak lagi mengalami menstruasi. Masa menopause yang terjadi karena perubahan hormone dalam tubuh seorang wanita biasanya terjadi pada usia 50-51 tahun. Namun ada juga menopause secara alami terjadi sebelum usia 50 tahun. ${ }^{7}$ Menopause juga akan dialami oleh seorang wanita muda yang belum mencapai usia tersebut yang mengalami pengangkatan rahim atau uterus yang dikenal dengan Hysterectomi, yang dsebabkan berbagai hal yang terjadi pada rahim wanita tersebut misalnya adanya tumor dan lain sebagainya. ${ }^{8}$ Bahkan menopause juga bisa dialami lebih awal oleh wanita perokok, namun sebaliknya akan terjadi lebih lama bagi wanita yang mengalami kebutaan sejak lahir. ${ }^{9}$ Beberapa fungsi yang sering mengalami gangguan bagi wanita menopause adalah terjadi pada bagian otak dan sistem sarap yang akan berakibat pada gangguan konsentrasi dan mudah lupa atau kesulitan dalam mengingat. Gangguan juga terjadi pada bagian tulang, biasanya akan mengalami osteoporosis atau kekeroposan tulang. ${ }^{10}$

c. Pascamenopause

\footnotetext{
${ }^{4}$ Emma, S. Wirakusumah, Tetap..., h. 2.

${ }^{5}$ Emma, S. Wirakusumah, Tetap..., h. 3.

${ }^{6}$ Yati Afiyanti \& Anggi Pratiwi, Seksualitas dan Kesehatan Reproduksi Perempuan, (Jakarta: PT Raja Grafindo Persada, 2016), h. 32.

7 Th. Endang Porwoastuti, Menopause..., h. 15.

8 Th. Endang Porwoastuti, Menopause..., h. 16.

${ }^{9}$ Rosetta Reitz, Menopause Suaru Pendekatan Positif (Jakarta: Bumi Aksara)..., h. 16.

${ }^{10}$ Th. Endang Porwoastuti, Menopause..., h. 14.
} 
Masa ini akan terjadi 3 hingga 5 tahun setelah terjadi menstruasi terakhir. Setiap wanita berbeda-beda menjalani fase ini, adakalanya terjadi bersamaan dengan pramenopause. Ketika wanita mulai berumur 40 tahun akan terjadi pengurangan secara responsif terhadap hormone pituitari dimana hal ini akan membuat wanita berkurang kesuburannya. Klimaksterium yang dialami pada masa itu menjadi sebuah peralihan dari tahun ketahun terhadap reproduktif seorang wanita dan kemudian berakhir pada masa senium atau lanjut usia yakni pada usia 65 tahun. ${ }^{11}$

2. Gejala Menopause

Pada umumnya gejala yang dialami wanita menopause dapat dibagi menjadi dua hal, yaitu:

a. Secara Fisiologis

Adalah sebuah perubahan yang terjadi pada organ reproduksi dan juga anggota tubuh lainnya, pada susunan ekstragenital, serta gejala klinis. ${ }^{12}$ Bagian yang akan mengalami perubahan pada organ reproduksi yaitu:

a) Uterus

Uterus atau rahim akan mengecil karena disebabkan menciutnya selaput lendir rahim atau juga disebut dengan atrofi endometrium, disebabkan hilangnya cairan dan berubahnya jaringan ikat antar sel. Miometrium atau otot rahim akan menonjol serta menebalnya pula pembuluh darah miometrium tersebut. ${ }^{13}$

b) Tuba Falopi

Tuba Falofi atau saluran telur menjadi lebih pendek kemudian menipis bahkan mengerut dan rambut getar dalam tubapun akan hilang. ${ }^{14}$

c) Ovarium

Ovarium atau indung telur mengalami perubahan akibat sebuah proses penuaan yang selektif yang akan mengganggu peredaran darah ovarium pada masa pramenopause dan siklus haid menjadi anovulasi atau tidak lagi mengeluarkan sel telur, dan ini akan diiringi dengan meningkatnya hormone gonadotropin yang mengakibatkan metabolisme pada hormone di ovarium menjadi lemah atau menciut dan jaringan pengikat menjadi banyak. Beberapa proses tersebut terbentuk secara genetik pada usia menopause, dan ini akan banyak menimbulkan keluhan-keluhan karena disebabkan hilangnya hormone estrogen. ${ }^{15}$

d) Cervix

Cervix atau leher rahim akan mengalami perubahan pada bagian leher rahim dan vagina atau liang senggama, jika pada cervix mengalami pemendekan akibat pengerutan sehingga tertutup oleh dinding

11 Th. Endang Porwoastuti, Menopause..., h. 17.

${ }^{12}$ Desiayani Nani, Fisiologi Manusia, (Jakarta: Penebar Swadaya Group, 2018), h. 110.

${ }^{13}$ Heffner. L.J, \& Schurt, D.J, At a Glance Sistem Reproduksi, (Jakarta: PT Gelora Aksara Pratama, 2008), h. 30

14 Th. Endang Porwoastuti, Menopause..., h. 20.

15 Th. Endang Porwoastuti, Menopause..., h. 22. 
vagina, dan ukuran pemendekannya akan menyerupai cervix fundus yaitu yang terjadi pada usia anak-anak atau adolesen. ${ }^{16}$

e) Vagina

Sementara yang terjadi pada bagian liang senggama atau vagina yaitu hilangnya lipatan-lipatan rugae dan berkurangnya elatisitas, mengencernya sekret vagina serta menurunnya korio piknotik yang kesemuanya itu terjadi karena penipisan dinding vagina. ${ }^{17}$

f) Vulva

Hal yang sama akan terjadi pula pada perubahan bagian mulut vagina atau vulva dimana hilangnya jaringan elastis dan lemak yang kemudian mengakibatkan pengerutan pada lipatan vulva yang terkadang disertai timbulnya rasa gatal karena atrofi dan sekret kulit yang menghilang dan ini ada hubungannya dengan dispareunia atau biasa disebut dengan nyeri pada saat melakukan senggama. Hal itu karena pengerutan pada bagian lubang vagina atau introitus. ${ }^{18}$

Dari perubahan-perubahan yang telah disebutkan, tentu akan berpengaruh pula pada anggota tubuh lainnya. Di antara yang mengikuti perubahan itu pada umumnya adalah:

a) Bagian dasar pinggul yang berkurangnya kekuatan dan elatisitasnya mengakibatkan lemah daya sokongnya diakibatkan menurunnya alat-alat kelamin pada bagian dalam. ${ }^{19}$

b) Bagian lubang pelepasan atau anus yang melemah dan menghilangnya lemak bagian bawah kulit, sehingga terjadi buang air besar dan kecil terkadang tidak berasa atau incontinensia alvi vagina. ${ }^{20}$

c) Bagian buli-buli atau kandung kemih yang mengalami perubahan dan mengakibatkan tidak bisa mengendalikan buang air kecil. Ini disebabkan karena aktifitas kendali sfingter dan otot kandung kemih atau detrusor menghilang. ${ }^{321}$

d) Bagian kelenjar payudara, yang juga mengalami pengurangan lemak pada bagian bawah kulit atau subcutan karena diserap, akibatnya parenkim atrofi dan lobulus menjadi kecil sementara jaringan stroma ikat fibrosa menjadi tebal dan bagian puting susu akan mengalami pengecilan dan tidak lagi erektil. Berkurangnya pigmen akan menjadi penyebab payudara menjadi kendor dan datar. ${ }^{422}$

e) Bagian pada susunan ekstragenital yakni terjadinya penimbunan lemak terutama pada bagian lengan, perut dan pinggul bagian bawah. Beberapa persen wanita yang sudah mengalami masa klimaterik mengalami penaikan berat badan yang sangat mencolok, ini karena adanya gangguan metabolisme karena menurunnya kadar estrogen. Ditambah Peningkatan gejolak panas pada tekanan darah mengakibatkan terjadinya hipertensi, kemudian peningkatan kolesterol,

\footnotetext{
16 Th. Endang Porwoastuti, Menopause..., h. 13.

17 Th. Endang Porwoastuti, Menopause..., h. 24.

18 Th. Endang Porwoastuti, Menopause..., h. 25.

${ }^{19}$ Saraswati, 52 Penyakit Perempuan, (Jogjakarta: Katahati, 2010), h. 218.

${ }^{20}$ Coob. J. Understanding Menopause, (London: Brtish Medical, 1993), h. 10.

${ }^{21}$ Coob. J. Understanding..., h. 12.

${ }^{22}$ Coob. J. Understanding..., h. 13.
} 
pengapuran dinding pembuluh darah atau biasa disebut aterosklerosis dimana akan mengenai pada bagian pembuluh darah menuju jantung yang bisa mengakibatkan matinya otot-otot jantung. Penurunan kadar estrogen juga berimbas pada bagian viriliasi atau bagian tumbuhnya rambut akan mengalami pengurangan. Selain hal di atas ketika wanita mulai menopause dimana kadar estrogen itu berkurang maka akan terjadi pengeroposan tulang atau osteoporosis karena berkurangnya kadar mineral pada tulang. ${ }^{23}$

f) Bagian selanjutnya yang akan mengalami gangguan yaitu adalah gejala klinis, dimana hal ini akan sangat sering dialami wanita yang telah menopause akibat kadar pengurangan estrogen dan progesterone. Di antaranya adalah memerahnya wajah atau hot flashes yang berawal dari bagian tubuh dan menyebar hingga ke bagian wajah. Gejala selanjutnya adalah semakin meningkatnya keringat dan disertai rasa dingain secara tiba-tiba, denyut jantung naik hingga 20\%, pada umumnya terjadi pada malam hari. Dan hal tersebut akan menimbulkan wanita menopause pada umumnya mengalami insomnia atau sulit tidur. ${ }^{24}$

b. Secara Psikologis.

Perubahan ini pada umumnya terjadi karena adanya perubahan fisik atau karena faktor perubahan tingkat hormone yang mengakibatkan ketidak seimbangan tingkat emosional seperti:

a) Mudah tersinggung atau irilatif dan rasa cemas yang berlebihan. ${ }^{25}$

b) Sulit mengingat dan hilangnya konsentrasi.

c) Timbulnya depresi yang kesemuanya ini akan mengganggu kehidupan sosial wanita tersebut.

d) Rasa khawatir yang berlebihan sebenarnya. Hal ini terkait dengan perubahan hormone dimana para wanita yang mengalami insomnia akan mengalami keletihan karena kurangnya waktu tidur.

e) Perasaan cemas. Hal ini timbul terkadang justru ketika akan melakukan hubungan intim dengan suaminya, yang merupakan simbol rasa cinta dan kemesraan pasangan tersebut. Ini dipicu karena perubahan pada bagian vagina yang kekurangan estrogen dan menjadi kering, sehingga terasa sakit dan mudah cidera ketika melakukan senggama. ${ }^{26}$

Gangguan psikis pada wanita yang mengalami menopause sebenarnya tidak mesti terjadi pada wanita lainnya, apa yang dialami oleh seorang wanita pada masa itu, tergantung pada keadaan masing-masing. Wanita yang memiliki tekanan hidup dan depresi pada umumnya mengalami gangguan psikologis sebagaimana disebutkan di atas seperti beberpa yang dialami responden sebagai berikut.

1. Profil Responden

Dari hasil penelitian yang dilakukan peneliti, maka jumlah responden yang diteliti berjumlah 10 orang yang ke semua responden adalah wanita paruh baya dengan

${ }^{23}$ Suparto, Sehat Menjelang Usia Senja, (Bandung: PT Remaja Rosdakarya, 1997), h. 34.

24 Suparto, Sehat..., h. 35.

${ }^{25}$ Desiayani Nani, Fisiologi..., h. 113.

${ }^{26}$ http://lifestyle.kompas.com, Pendekatan Kesehatan Jiwa Wanita Menopause. 
rentang usia 45 sampai dengan 60 tahun dengan status masih memiliki suami. Dari kesepuluh responden peneliti mengambil satu responden dari 10 RT yang berada di Kelurahan Loa Bakung, dengan masing-masing RT diambil satu orang wanita sebagai responden.

\begin{tabular}{|l|l|l|l|l|l|}
\hline No & Nama & Umur & Pendidikan & Pekerjaan & Keterangan \\
\hline 1 & LCN & 49 & SMA & IRT & Postmenopause \\
\hline 2 & NRH & 60 & SD & IRT & Pascamenopause \\
\hline 3 & RC & 54 & S1 & IRT & Pascamenopause \\
\hline 4 & RSM & 54 & SD & IRT & Pascamenopause \\
\hline 5 & HP & 54 & S1 & GURU & PascaMenopuase \\
\hline 6 & JMH & 60 & SD & IRT & PacaMenopause \\
\hline 7 & SW & 56 & S1 & PNS & Pascamenopause \\
\hline 8 & JM & 58 & SD & IRT & Pascamenopause \\
\hline 9 & AZ & 45 & S1 & GURU & Postmenopause \\
\hline 10 & TR & 53 & S1 & GURU & Pascamenopause \\
\hline
\end{tabular}

Data Responden

Dari 10 responden tersebut peneliti secara instensif menggali dan mendapatkan informasi dan data secara langsung tentang pengetahuan mereka tentang menopause serta bagaimana kesepuluh wanita itu menjalani kehidupan rumah tangganya serta upaya apa saja yang mereka lakukan untuk menjaga keharmonisan rumah tangga setelah terjadinya menopause.

Dari beberapa poin penting yang peneliti tanyakan kepada responden sebagai upaya untuk mendapatkan informasi yang dibutuhkan dalam penelitian ini, maka dapat peneliti uraikan sebagai berikut:

1. Persepsi Responden Tentang Menopause

Ibu Lcn Memahami bahwa menopause adalah sebuah takdir yang harus dijalani oleh seorang wanita dan tidak dapat dihindari meskipun dengan berbagai macam cara. Sedangkan dua responden lain yaitu Ibu Nrh dan ibu Rsm tidak sama sekali memahami berhentinya menstruasi seorang wanita adalah menopause selanjutnya ibu Rc, ibu Sw, ibu Tr dan ibu Hp memahami tentang menopause merupakan berhentinya seorang wanita menstruasi dan menganggap apabila seorang wanita telah menopause adalah wanita tua maka hilangnya kesuburannya dan tidak akan bisa mempunyai anak. Ibu 
Jmh senada dengan beberapa responden bahwa menopause adalah wanita yang tidak lagi menstruasi dan pengetahuan ini justru didapatkan dari suaminya. Menurutnya Ibu Jm menopause adalah sesuatu yang sangat ditunggu karena aktifitasnya tidak terganggu oleh menstruasi adapun ibu Az berpendapat bahwa menopause sama halnya dengan uban yang tumbuh di kepala artinya seorang wanita telah memasuki masa tua.

Dari persepsi para responden tentang menopause dapat ditarik kesimpulan bahwa 8 responden memahami betul tentang menopause dengan pendapat yang hampir sama dan persepsi ini terjadi bisa jadi karena pengaruh dari latar belakang pendidikan para wanita tersebut dan atau informasi dari orang lain. Sedangkan 2 responden lainnya hanya tidak mengetahui istilah menopause yang merupakan berhentinya seorang wanita menstruasi. Sebagaimana telah dijelaskan sebelumnya bahwa menopause merupakan sebuah bahasa dari Yunani, yang maksudnya adalah "bulan" atau penghentian sementara. Secara istilah yaitu berhentinya menstruasi secara permanen dan berakhir pula masa reproduksi. Masa menopause ini ditandai dengan berhentinya menstruasi karena berubahnya hormone. Ahli kesehatan biasa mengunakan ini dengan istilah klimakterium yaitu terjadinya perubahan hormone karena menurunnya kadar estrogen dan progesterone yang dihasilkan indung telur, hal ini biasanya terjadi ketika wanita tersebut masih mengalami menstruasi beberapa tahun sebelum terjadinya menopause.

2. Usia Menopause Para Responden

Beberapa responden mengalami menopause pada umumnya memasuki usia paruh baya yaitu 50 tahun sebanyak 4 responden, kemudian 3 responden pada usia 49 tahun dan selebihnya 48 dan 47 tahun masing-masing satu responden, kemudian dari 9 responden ada satu yang lebih awal mengalami menopause yaitu usia 43 tahun ini dialami ibu Az.

Usia menopause yang dialami responden sebenarnya adalah usia yang memang pada umumnya terjadi, karena pada usia tersebut akan terjadinya penurunan kadar hormone estrogen. Namun demikian pola hidup tentu akan sangat mempengaruhi lambat atau cepatnya seorang wanita menopause selain adanya gangguan medis dan penggunaan alat kontrasepsi juga karena faktor keturunan. ${ }^{14}$

3. Sindrom Menopause Terhadap Responden

Beberapa responden mengalami hal berbeda ketika pertama terjadi menopause, beberapa sindrom yang dialami di antaranya adalah sering merasa pusing tanpa sebab, mual, sulit tidur kadang merasa panas sehingga berkeringat dan tiba-tiba menggigil ini dialami ibu Sw dan ibu Jmh dan bahkan ada yang merasakan sakit seperti halnya saat akan melahirkan ketika terjadi menstruasi terakhirnya, ini dialami oleh ibu Lcn. Begitu pula Ibu Nrh dan ibu Hp saat menopause mengalami hal yang sama dengan ibu Lcn yaitu terjadi menstruasi yang sangat banyak dan waktu menstruasinya menjadi sangat lama akan tetapi keduanya tidak merasakan sakit apapun seperti yang dialami ibu Lcn.

Berbeda yang dialami oleh ibu Rc dan ibu Az sindrom yang terjadi jutru lebih kepada gangguan psikologis yaitu saat pertama menopause dia menjadi shock ketika

14 Emma, S. Wirakusumah, Tetap Sehat, Cantik, dan Bahagia Di Masa Menopuase Dengan Terapi Estrogen Alami, (Jakarta: Gramedia Pustaka Utama, 2003), h. 8.

Volume 3, Nomor 1, Juni 2021 (35-50) 
mengetahui bahwa dirinya tidak lagi menstruasi. Begitu pula dengan ibu Az, yang dialaminya justru lebih parah daripada ibu Rc, dia divonis dokter mengalami anxiety disorder yakni rasa cemas yang berlebihan tanpa sebab sehingga membuat kesehatannya menurun drastis dan sangat mengganggu aktifitasnya. Sedangkan 3 responden lain yaitu ibu Rsm, ibu Jm dan ibu Tr saat terjadi menopause tidak mengalami hal tersebut sebagaimana 7 responden, hanya saja proses menstruasinya yang mengalami penurunan dan akhirnya berhenti sama sekali.

Para responden pada umumnya mengalami perubahan fisik dan bahkan gangguan psikologi serta gangguan kesehatan ringan dan berat, pada masa post dan pascamenopause. Gangguan yang ringan yaitu sakit pada persendian biasanya dialami wanita postmenopause, namun bisa saja justru wanita yang masih potmenopause tersebut mengalami gangguan kesehatan berat, sedangkan beberapa wanita dimasa pascamenopuase pada usia senium (tua) umumnya mengalami gangguan kesehatan berat seperti hipertensi dan kolesterol tinggi serta diabetes. Hal ini terjadi karena pada masa menopause hormone estrogen dan progesterone yang sangat penting bagi tubuh wanita dan dibutuhkan akan mengalami pengurangan, selain itu faktor lainnya yaitu kurangnya pola hidup sehat dan tidak melakukan aktifitas olahraga dan adanya rasa kurang percaya diri.

4. Gangguan Kesehatan Pada Responden di Masa Menopause

Responden yang mengalami gangguan kesehatan pada masa menopause pada umumnya setelah memasuki usia senium (tua), gangguan yang banyak dialami adalah nyeri pada persendian dan kolesterol bahkan ada di antaranya yang mengalami gangguan medis yang cukup berat seperti hipertensi dan diabetes. Sebagaimana diketahui bahwa hormone estrogen yang dimiliki seorang wanita akan berkurang pada masa menopause. Fungsi hormone estrogen sendiri adalah untuk meningkatkan hormone seks pada wanita yang dihasilkan oleh ovarium, serta kelenjar adrenalin yang merupakan penghasil sifat feminim atau kewanitaan dan sangat berpengaruh untuk biologis tubuh seorang wanita. ${ }^{15}$ Oleh karenanya sangatlah wajar jika seorang wanita yang telah menopause mengalami beberapa gangguan pada kesehatannya mengingat usia dan penurunan kadar hormone estrogen yang sangat berpengaruh pada keadaan tubuh seorang wanita.

5. Upaya Menjaga Keharmonisan Rumah Tangga di Masa Menopause

Meskipun telah menopause para responden berupaya untuk menjaga bagaimana rumah tanggannya bisa utuh dan berjalan harmonis, dari 10 responden 2 di antaranya yaitu ibu Jmh dan ibu Jm membiarkan suaminya untuk berpoligami untuk dapat membantu suaminya menyalurkan hasrat biologisnya karena 2 responden tersebut tidak dapat lagi melayani suaminya untuk hubungan intim sementara suaminya masih menggebu dalam hal tersebut. Adapun ibu Nrh meskipun tidak lagi melayani suaminya berhubungan intim selama 5 tahun terakhir ini namun dia tidak ingin suaminya melakukan poligami dan dia berupaya hanya dengan meyakinkan suaminya meskipun tidak melakukan hubungan biologis lagi dapat saja harmonis dengan sama-sama mendekatkan diri kepada Allah dan lebih fokus melakukan ibadah. Dan hal ini juga terjadi kepada ibu Hp sejak awal menopause dia sudah tidak lagi berhubungan intim

${ }^{15}$ Emma, S. Wirakusumah, Tetap..., h. 6. 
selain kehilangan selera karena menopause juga karena faktor kelelahan karena menjadi tulang punggung keluarganya.

Selanjutnya dari 10 wanita menopause itu ada 4 wanita di masa pascamenopause yang sudah tidak pernah lagi melakukan hubungan intim bersama suaminya, sedangkan suaminya masih membutuhkan itu. Alasan 3 wanita tersebut adalah merasa tidak sanggup lagi karena sakit pada bagian vagina sehingga merasa trauma, selanjutnya enggan karena tidak mempunyai keinginan lagi serta merasa geli ketika melakukan hubungan intim. Dan 6 wanita lainnya masih melayani suaminya dalam hubungan intim meskipun mengalami penurunan selera dan merasa kurang menikmati bahkan timbul rasa perih saat melakukan hubungan sehingga harus menggunakan bantuan berupa minyak ataupun handbody dan lainnya untuk lubrikasi.

Dari problem yang dialami oleh para wanita menopause tersebut maka Islam menegaskan bahwa seorang isteri memang wajib melayani suaminya yang masih berkeinginan untuk melakukan hubungan intim, meskipun wanita tersebut sudah tidak mempunyai selera, karena Islam tidak membatasi usia seorang suami atau isteri untuk saling menjalankan kewajibannya tersebut jika masing-masing atau salah satunya masih menginginkan hal itu. Sebagaimana firman Allah dalam Al-Qur'an pada Surah ABaqarah ayat 223: ${ }^{14}$

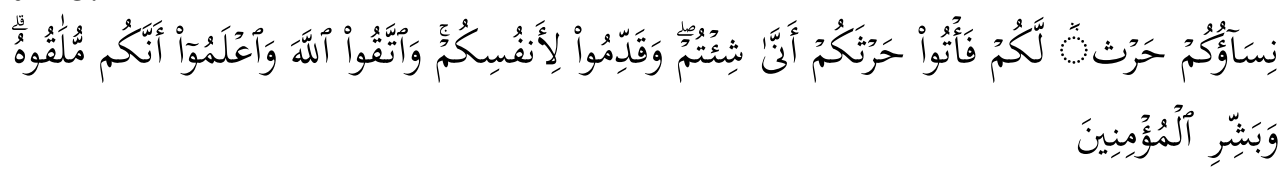

Artinya: Isteri- isterimu adalah ladang bagimu, maka datangilah ladangmu itu kapan saja dengan cara yang kamu sukai. Dan utamakanlah yang baik untuk dirimu. Bertakwalah kepada Allah dan ketahuilah bahwa kamu (kelak) menemuiNya. Dan sampaikanlah kabar gembira kepada orang yang beriman.

Dalam ayat ini seorang suami dapat meminta kapan saja kepada isteri untuk digauli dan isteri wajib mentaati suaminya dalam keadaan apapun terkecuali dalam hal bermaksiat kepada Allah dan Rasulnya, sebagaimana juga ditegaskan oleh Nabi SAW dalam sebuah hadis yang diriwayatkan oleh At-Tirmidzi yang artinya: "Jika seorang isteri dipanggil oleh suaminya karena perlu, maka segeralah datang walaupun dia sedang memasak."15 Hadis ini menunjukan bahwa ketaatan seorang isteri terhadap suaminya adalah merupakan kewajiban dimanapun dan kapanpun. Artinya bagi seorang wanita yang menopausepun seharusnya tidak semestinya menolak ajakan suaminya yang masih memiliki keinginan untuk melakukan hubungan intim sebagaimana yang dilakukan oleh 4 orang responden. Namun di dalam Islam sesungguhnya hubungan biologis harus dilakukan dengan saling ada keinginan dan keridhoan suami isteri tersebut yaitu suami hendaknya meminta kepada isteri dengan cara yang ma'ruf sebagaimana yang terdapat pada surah An-Nisa ayat 19:16

Ayat tersebut sesungguhnya mengharapkan bagi seorang suami untuk mendatangi isterinya dengan cara yang baik dan hendaknya tidak memaksakan

14 Depertemen Agama RI, Al-Qur'an dan Terjemah, cetakan ke-10, (Bandung: CV Penerbit Diponegoro, 2005), h. 35.

${ }^{15}$ Muhammad Abu Zahrah, Al-Ahwal..., h. 19.

${ }^{16}$ Ahmad Basyir Azha \& Fauzi Rahman, Keluarga Sakinah Keluarga Syurgawi, (Yogyakarta: Titian Illahi Press, 1994), h. 23. 
kehendaknya kepada isteri yang memang mempunyai uzdur, karena pada dasarnya saat melakukan hubungan intim harus ada kenyamanan dan ketenangan. Namun jika ada seorang isteri yang melakukan penolakan dan seorang suami juga melakukan pemaksaan maka hal ini karena keterbatasan pengetahuannya tentang kewajiban suami isteri dan minimnya pengetahuan tentang sebuah solusi bagaimana sebaiknya melakukan hubungan intim di usia senium (tua) dengan berbagai cara dan alat bantu.

Adanya ikatan sebagai suami dan isteri adalah sebab terjadinya hak dan kewajiban serta untuk meraih tujuan yang sama yaitu kebahagiaan dan kedamaian yang kekal serta adanya kasih sayang sepanjang masa. Hal ini akan didapat bagi kedua pasangan tersebut jika masing-masing mamahami dan menjalankan kewajibannya, sehingga akan tercapai sakinah mawaddah dan rahmah, namun jika ada salah satu hal yang menjadi pokok dasar kebutuhan dalam rumah tangga tidak dapat terpenuhi maka hilanglah makna sakinah mawaddah dan rahmah dalam rumah tangga tersebut. Islam menginginkan setiap rumah tangga dibangun dengan konsep sakinah mawaddah dan rahmah sebagaimana ditegaskan pada surah Ar-Rum ayat 21:17

\section{Kesimpulan}

Dari uraian yang telah peneliti jelaskan pada poin-poin sebelumnya maka dapat disimpulkan sebagai berikut.

1. Menopause atau berhentinya menstruasi pada seorang wanita sangat berpengaruh pada kehidupan rumah tangganya, sehingga beberapa wanita enggan untuk melayani suaminya dalam melakukan hubungan intim dengan alasan sakit saat berhubungan dikarenakan kurangnya hormone estrogen sehingga sangat berpengaruh pada gairah biologis. Berkurangnya lubrikasi pada masa klimakterium inilah yang membuat vagina menjadi kering sehingga kenikmatan bercinta menurun tajam. Selain sangat berpengaruh pada hubungan biologis menopause juga berpengaruh pada kesehatan seorang wanita yang mulai memasuki usia senium (tua), di mana masa ini rentan terjadi berbagai penyakit klinis, oleh karenanya pola hidup sehat harus tetap dilakukan pada masa post atau pascamenopause.

2. Upaya yang dilakukan para wanita agar tetap bisa menjaga keutuhan dan keharmonisan rumah tangganya sangat beraneka, ada yang melakukan perawatan diri dan kesehatannya agar tetap bisa melayani suaminya dengan maksimal, ada pula yang tampil apa adanya dengan hanya meyakinkan suaminya dengan memberikan pengertian tentang keadaannya, bahkan ada yang merelakan suaminya berpoligami. Oleh karenanya hak dan kewajiban dalam rumah tangga harus tetap dilaksanakn kapan dan di manapun, sekalipun seorang isteri telah mengalami menopause, seorang isteri wajib melaksanakan apa yang diinginkan seorang suami selama itu bukan berbuat maksiat kepada Allah dan Rasulnya. Namun seorang suami juga hendaknya tidak memaksakan keinginannya ketika seorang isteri didapati sedang mengalami udzur. Islam menginginkan hubungan suami isteri harus dijalankan

17 Ibnu Shalih bin Hasbullah Abu Muhammad, Tuntunan Menggapai Keluarga Sakinah, (Jakarta: Pustaka Ibnu Umar, 2015), h. 14. 
dengan ma'ruf, saling adanya keridhoan antara keduanya sehingga rumah tangga yang sudah dibina selama ini tetap menjadi keluarga yang sakinah mawaddah dan rahmah, yaitu selalu ada ketenangan, kedamaian, cinta dan kasih sayang, meskipun ada di antara hak dan kewajiban tidak dapat lagi dilaksanakan, akan tetapi rasa kasih sayang harus dipupuk dan diberikan kepada pasangan yang telah sama-sama memasuki usia senium (tua).

\section{Daftar Pustaka}

An-Nu'aimi Kamal Thariq, Psikologi Suami Istri, Yogyakarta: Mitra Pustaka 2005).

Afiyanti Yati \& Pratiwi Anggi, Seksualitas Dan Kesehatan Reproduksi Perempuan, Jakarta: Rajawali Pers, 2016).

Aubrey M. Hill, Viropause- Andropause atau Menopause Laki- laki, (Jogjakarta: Pustaka Pelajar 2010).

Al-Qorni Aidha, Tafsir Al-Muyassar, (Jakarta: Qisthi Press, 2007).

Ahmad Nur, "Konseling Pernikahan Berbasis Asmara" (As-Sakinah, Mawaddah, Warahmah), dalam Jurnal Konseling Religi, (Stain Kudus: Jawa Tengah Vol. 7, No. 2 Tahun 2016).

Basri, Merawat Cinta Kasih, Yogyakarta: Pustaka Pelajar, 1996).

Basri Hasan, Keluarga Sakinah Tinjauan Psikologi dan Agama, (Jogjakarta: Pustaka Pelajar, 2002).

Basyir Azha Ahmad r \& Rahman Fauzi, Keluarga Sakinah Keluarga Syurgawi, (Yogyakarta: Titian Illahi Press, 1994).

Cristiani, Retnowati Sofia dan Purwaningsih Hayu Esti, Hubungan Persepsi Tentang Menopause Dengan Tingkat Kecemasan Pada Wanita yang Menghadapi Menopause, dalam jurnal Psikologi, Universitas Gadjah Mada, 2000).

Chodijah Siti, Karakteristik Keluarga Sakinah Dalam Islam, (Jurnal Rausyan Fikr, Volume 14, No 1.

Depertemen Agama RI, Al-Qur'an dan Terjemah, cetakan ke-10, (Bandung: CV Penerbit Diponegoro, 2005).

Depertemen Agama RI, Petunjuk Teknis Pembinaan Gerakan Keluarga Sakinah, (Ditjen Bimas Islam dan Penyelenggaran Haji Direktorat Urusan Agama Islam, 2005).

D. Lestary, Seluk Beluk Menopause, Jogjakarta: Garailmu, 2010).

Fadhlun Mokh., Nusyuz Menurut Pendapat Imam Abu Hanifah dan Imam Syafi'i, (UIN Sunan Kali Jaga, Jogjakarta).

Indrias Destia Hesty, Tesis, Hubungan Antara Perubahan Fisik Dengan Perubahan Psikologi Wanita Pada Masa Menopause di Kelurahan Pucang Sawit, Kecamatan Jebres, (Fakultas Ilmu Kesehatan, Universitas Muhammadiyah Surakarta 2015).

Hadis Riwayat An-Nasa'i, No. 3231, dalam kitab An-Nikaah no. 7373. Hadis ini dihasankan oleh Syaikh Al-Bani dalam kitab Ash-Shahihah no. 1838.

Heffner Linda. J \& Schrust. DJ, At a Glance Sistem Reproduksi, (Jakarta: PT Global Aksara Pratama, 2008).

Hasbullah Abu Muhammad Ibnu Shalih bin, Tuntunan Menggapai Keluarga Sakinah, (Jakarta: Pustaka Ibnu Umar, 2015).

http//wnpg.lipi.go.id. Pangan dan Gizi Masa Depan: Meningkatkan Produktifitas dan Daya Saing Bangsa. 
50 Upaya Wanita Menopause dalam Menjaga .....

http://hellodokter.com, Menunda Menopause dengan Konsumsi Makanan Sehat.

http://women'shealth.ned.id.

http://www.alodeokter.com/ menstruasi/menopuase.

http://id.beritasatu.com/family/Ini-Keluhan-Wanita-Saat-Menopuase.

http://lifestyle.kompas.com, Pendekatan Kesehatan Jiwa Wanita Menopause.

http://mahabahforever.blokspot.com/Makna-Sakinah-Mawaddah-Rahmah.

Irianto Koes, Seksologi Kesehatan, (Bandung: Alfabeta, 2014).

J. Coob, Understanding Menopause, (London: Brtish Medical, 1993).

Reitz Rosetta, Menopause Suaru Pendekatan Positif (Jakarta: Bumi Aksara).

Kamus Besar Bahasa Indonesia, (Jakarta: Depertemen Pendidikan dan Kebudayaan, 1989). 